\title{
Fuzzy Expert System of Dental and Oral Disease with Certainty Factor
}

\author{
Billy Ambara ${ }^{1}$, Darma Putra ${ }^{2}$ and Dwi Rusjayanthi ${ }^{3}$ \\ ${ }^{1}$ Department of Information Technology, Udayana University \\ Denpasar, Bali/80361, Indonesia \\ ${ }^{2}$ Department of Information Technology, Udayana University \\ Denpasar, Bali/80361, Indonesia \\ ${ }^{3}$ Department of Information Technology, Udayana University \\ Denpasar, Bali/80361, Indonesia
}

\begin{abstract}
Dental and oral is body organ located on the face, so that the health of the teeth and mouth is very important. Some of people fell fear to dentist because it take times and expensive cost. Knowledge improvement could assist expert to insert, update and delete data diseases so that the system remains accurate and up to date. Fuzzy logic method is used to obtain the user's trust value (wi), while the certainty factor method is used to get an answer from the system diagnostics. After the user has answered about 27 questions, then the system displays the result of diagnosis based on the users answers. The diagnosis results are used to obtain the accuracy of the system based on comparison of the results of the expert diagnosis with the diagnosis results. Accuracy of Expert System with Dental and Oral Disease with Fuzzy and Certainty Factor obtained the result is $94,627 \%$.

Keywords: Expert System, Dental and Oral Desease, Fuzzy Logic, Certainty Factor.
\end{abstract}

\section{Introduction}

Dental and oral is body organ located on the face, so that the health of the teeth and mouth is very important. Mostly, people ignore mouth and teeth health problem. Some of people fell fear to dentist because it take times and expensive cost. The dental and oral disease can affect people in every age. Unhealty lifestyle can caused a person to oral and dental disease, such as: pulpitis reversible, pulpitis irreversible, nekrosis pulpa, dental abscess, gingivitis, dental fraktur, periondontitis, stomatitis, halitosis, but not all of these diseases affected by unhealty lifestyle, some caused by bacterial agent.

Development of an application expert system for dental and oral diseases, hopefully can efficient the cost, times, and the consultation can be done without teeth tools refers that commonly used so can avoid the patien fear during the consultation. Research related to Expert System of Dental and Oral Diseases with fuzzy logic method, and certainty factor method that have been explained have similiarity and difference with developed research, such as: "A Fuzzy Expert System Design for Diagnosis of Periodontal Dental Diseases", "Dental Disease Identification Using Fuzzy Inference System", and "Rancang Bangun Sistem Pakar untuk Diagnosis Penyakit Mulut dan Gigi dengan Metode Fuzzy Logic", talking about dental and oral diseases with applying fuzzy logic method, while this research developed by applying fuzzy logic method and certainty factor method [1-3]. Research titled "Sistem Pakar Mendiagnosa Penyakit Infeksi Gigi dan Mulut pada Manusia menggunakan Metode Certainty Factor", also had same thing by using certainty factor method, while this research developed by applying fuzzy logic method and certainty factor method [4]. Research titled "Sistem Pakar Diagnosa Penyakit Kulit dan Kelamin dengan Metode Certainty Factor dan Fuzzy Logic", also had same thing by using the same method, but with difference object [5]. Research titled "Sistem Pakar Diagnosa Penyakit Tanaman Padi Berbasis Web dengan Forward dan Backward Chaining", also had same thing by using forward chaining for inference engine, but with difference of object and method [6]. Research titled "The Analysis of Comparison of Expert System of Diagnosing Dog Disease by Certainty Factor Method and Dempster-Shafer Method", also had same thing by using certainty factor method, while this research developed by applying fuzzy logic method and certainty factor method with object dental and oral diseases[7]. Research titled "Fuzzy Knowledge-based System with Uncertainty for Tropical Infectious Disease Diagnosis", also had same thing by using the same method, but with difference object [8]. 
This research, developed application can diagnose of dental and oral disease with fuzzy logic method and certainty factor method. Development Expert System for Dental and Oral Disease, hopefully can assist people because can be anywhere and anytime access. Development Expert System for Dental and Oral Disease, so there facilities explanatory and knowledge improvement. Knowledge improvement could assist expert for done insert, update and delete data diseases so that the system remains accurate and up to date.

\section{Methodology}

Methodology discusses about steps in acquisition of knowledge where it will be used in this paper Expert System for Dental and Oral Diseases, and to discuss the appropriate method to diagnose this paper related to the also frequently occured problems by the users.

\subsection{Expert System Architecture}

Expert system architecture discribes features to develop the expert system. Expert system architecture can be seen in the Figure 1.

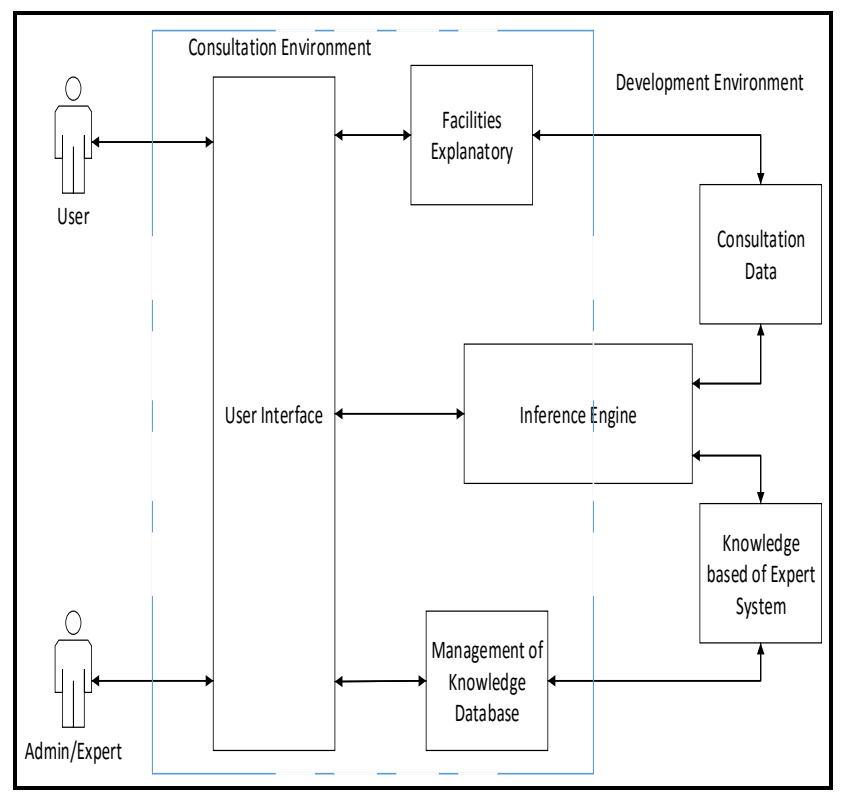

Fig. 1 Expert system architecture.

Expert system architecture in the Fig. 1 is a general description of the expert system. Expert system architecture consists of admin and user. The facilities of the expert system, such as: user interface, facilities explanatory, data consultation data, inferences engine,
Expert system knowledge base, and management of knowledge database [9-10].

a. User interface is a view that is used for communication between systems and users of the expert system.

b. Facilities explanatory is a module that can provide information to the user about the direction of reasoning in order to get the desired result.

c. Consultation data is a module that can provide information on the consultations that have been carried out.

d. Inferences engine is a computer program that provides the methodology of reasoning about the information to the knowledge base and the workplace memory, as well as to formulate conclusions.

e. Expert system knowledge base is a collection of knowledge in a particular field for understanding, formulation and problem resolution that is composed of two elements of facts and rules.

f. Management of knowledge database is a module to create, to update, and to delete a process of accumulation, transfer and transformation of skills / expertise based sources of knowledge to solve problems in a computer program. Management of knowledge database can knowledge acquisition from the expert with 27 symptom and 9 diseases [11-12].

\subsection{Diagnose Method}

Diagnose method is the method to using for total persentage certainty system from diseases, such as: fuzzy logic method and certainty factor method. Fuzzy logic method has high and low limit values specified. Afterwards. The values specified from the former method will be processed through Certainty factor method in order to obtain the value of user Certainty Factor. The Certainty Factor also in order to obtain the value of expert certainty factor specified.

\subsubsection{Fuzzy Logic Method}

Membership function is discribe by a curve which presents description of the insert data into membership values which has the interval between 0 and 1 . Value of membership has multiple functions [13-14]. Those functions are determined as follows.

a. Membership Function of Fever

Membership function of fever including the symptoms of fever. Fever is an increase in body temperature like normal human body temperature in the interval $35^{\circ} \mathrm{C}-37^{\circ} \mathrm{C}$. The 
set of fuzzy on the membership function of fever has interval, such as: Table 1 and membership curve in Fig. 2.

Table 1: Membership Function of Fever

\begin{tabular}{|c|l|l|}
\hline Variabel Input & \multicolumn{1}{|c|}{ Interval } & \multicolumn{1}{c|}{ Fuzzy Set } \\
\hline \multirow{4}{*}{$\begin{array}{c}\text { Membership } \\
\text { Function of Fever }\end{array}$} & $<36$ & Not Sure \\
\cline { 2 - 3 } & $35-37$ & Sure \\
\cline { 2 - 3 } & $36-42$ & Very Sure \\
\hline
\end{tabular}

Classification Membership function of fever in Table 1 is a classification based on the value of the interval that has a fuzzy set. The interval value can be illustrated in Fig. 2 .

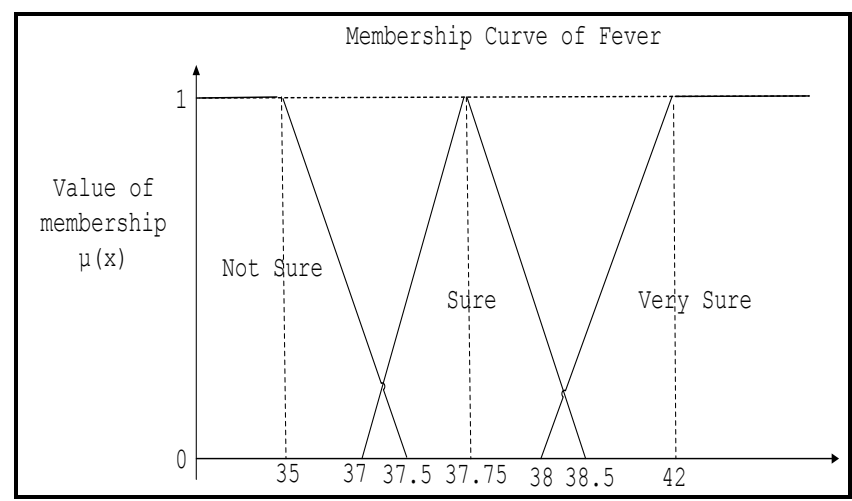

Fig. 2 Membership curve of fever.

Fig. 2 is membership curve of fever with value of membership 0 until 1 in the range of 35 until 42 for the data input. Based on the membership curve, then the membership function as follows.

$$
\begin{aligned}
& \mu_{\text {NotSure }}(x)= \\
& \left\{\begin{array}{c}
1, x \leq 35 \\
\frac{37.5-x}{37.5-35}, 35 \leq x \leq 37.5 \\
0, x \geq 37.5
\end{array}\right\} \\
& \mu_{\text {Sure }}(x)=\left\{\begin{array}{c}
0 ; x \leq 37 \text { or } x \geq 38.5 \\
\frac{x-37}{37+3.75} ; 37 \leq x \leq 37.75 \\
\frac{38.5-x}{38.5-3.75} ; 37.75 \leq x \leq 38.5 \\
1 ; 37.5=x
\end{array}\right\} \\
& \mu_{\text {Very Sure }}(x)=\left\{\begin{array}{cl}
0, & x \leq 38 \\
\frac{42-x}{42-38,} & 38 \leq x \leq 42 \\
1, & x \geq 42
\end{array}\right\}
\end{aligned}
$$

b. Membership Function of Except Fever Membership function of except fever are otherwise normal if it is in the interval 0-40. The set of fuzzy on the membership function of except fever has interval, such as: Table 2 and membership curve in Fig. 3.

Table 2: Membership Function of Except Fever

\begin{tabular}{|l|l|l|}
\hline Variabel Input & \multicolumn{1}{|c|}{ Interval } & \multicolumn{1}{|c|}{ Fuzzy Set } \\
\hline \multirow{3}{*}{$\begin{array}{c}\text { Membership } \\
\text { Function of } \\
\text { Except Fever }\end{array}$} & $0-40$ & Not Sure \\
\cline { 2 - 3 } & $30-70$ & Sure \\
\cline { 2 - 3 } & $60-100$ & Very Sure \\
\hline
\end{tabular}

Classification Membership function of except fever in Table 2 is a classification based on the value of the interval that has a fuzzy set. The interval value can be illustrated in Fig. 3.

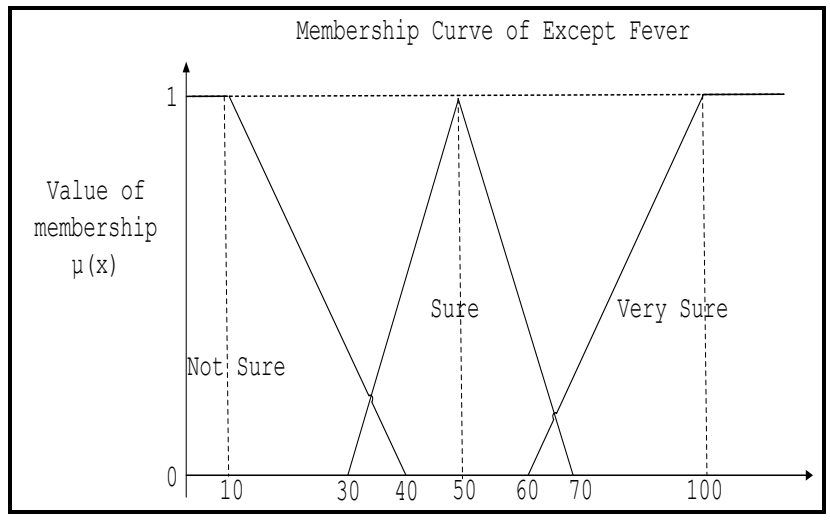

Fig. 3 Membership curve of except fever.

Fig. 3 is curve of membership curve of except fever with value of membership 0 until 1 and membership curve of except fever is 0 until 100 for the data input. Based on the membership curve, then the membership function as follows.

$$
\begin{aligned}
& \mu_{\text {Not Sure }}(x)=\left\{\begin{array}{c}
1 ; x \leq 10 \\
\frac{40-x}{40-10} ; 10 \leq x \leq 40 \\
0 ; x \geq 40
\end{array}\right\} \\
& \mu_{\text {Sure }}(x)=\left\{\begin{array}{c}
0 ; x \leq 30 \text { atou } x \geq 70 \\
\frac{x-30}{50-30} ; 30 \leq x \leq 50 \\
\frac{70-x}{70-50} ; 50 \leq x \leq 70 \\
1 ; 50=x
\end{array}\right\}
\end{aligned}
$$




$$
\mu_{\text {Very Surg }}(x)=\left\{\begin{array}{c}
1 ; x \geq 100 \\
\frac{x-60}{100-60} ; 60<x<100 \\
0 ; x \leq 60
\end{array}\right\} .
$$

Defuzzification is the last step in the fuzzy logic system where the aim is to convert every inference engine results expressed in the form of fuzzy sets into real numbers. Defuzzification process is done by using the defuzzification method, to sum up the average weight the equation is as follows [9], [13].

$$
\text { FinalResult }=\frac{\sum_{i=1}^{W} w_{i} z_{\hat{i}}}{\sum_{i=1}^{W} z_{i}}
$$

$\sum_{i=1}^{N} \quad:$ Total (Sum) $i$ consist of 1 to the $N$.

$w \quad$ : Variables that symbolizes weight. Value $w$ obtained from function min is $w i=\operatorname{Min}((x),(y))$ from weight user.

: Variable that symbolizes decisions. value $z$ obtained from weight expert.

\subsubsection{Certainty Factor Method}

Certainty Factor proposed by Shortliffe and Buchanan in 1975 to accommodate the uncertainty of thought (inexact reasoning) of an expert. This theory evolved simultaneously with the creation of the expert system MYCIN. MYCIN development team noted that doctors often analyze the existing information by expressions such as: maybe, probably, almost certainly, and so forth. MYCIN team using certainty factor to accommodate the expert in order to describe the level of certainty to the problems being faced [13],[15-16]. The level of certainty by the experts defined by utilizing Certainty Factor as follows.

$$
C F(H, E)=M B(H, E)-M D(H, E)
$$

$C F(H, E) \quad$ : Certainty factor hypothesis $(H)$ that is affected by symptoms $(E)$.

$M B(H, E)$ : The level of certainty in the hypothesis $(H)$ that is affected by the symptoms of $(E)$.

$M D(H, E):$ The level of uncertainty in the hypothesis $(H)$ that is affected by the symptoms of $(E)$.

Basic formula of Certainty Factor in the form of a rule if $\mathrm{E}$ then $\mathrm{H}$ [13], [15-16], as follows.

$$
C F(H, e)=C F(E, e) * C F(H, E)
$$

$C F(E, e)$ : Certainty factor symptoms $(E)$ that are affected by the symptoms $(e)$.

$C F(H, e)$ : Certainty factor hypothesis $(H)$ that are affected by the symptoms $(e)$.

$C F(H, E)$ : Certainty factor hypothesis $(H)$ assuming symptoms that are exactly known, when $C F(E, e)=1$.

Certainty Factor formula for some rules that lead to the same disease can be written as follows [10],[15-16].

$C F(H)=\left(C F(H, e)_{(i)}+C F(H)_{(j)}\right)-\left(C F(H, e)_{(i)} * C F(H)_{(j)}\right)$

CF $(H, e) \quad$ : Certainty factor hypothesis $(H)$ that are affected by the symptoms $(e)$.

$\mathrm{CF}(\mathrm{H}) \quad$ : Certainty factor hypothesis (diseases).

$i \quad$ : Consist of first data until the $N$ data.

$J \quad$ : Consist of zero data until the $N$ data.

\section{Experiment and Result}

Experiment and results are the outcome of testing of the developed system. Testing Expert System for Dental and Oral Diseases using Fuzzy Logic Method and Certainty Factor Method to get the results, so it can be used to analyze the accuracy of Expert System for Dental and Oral Diseases.

\subsection{Experiment}

Fig. 4 is a test of Expert System for Dental and Oral Diseases using Fuzzy Logic Method and Certainty Factor Method with a question containing the fuzzy of body temperature users. Answer input of body temperature is body temperature values of users in consultation.

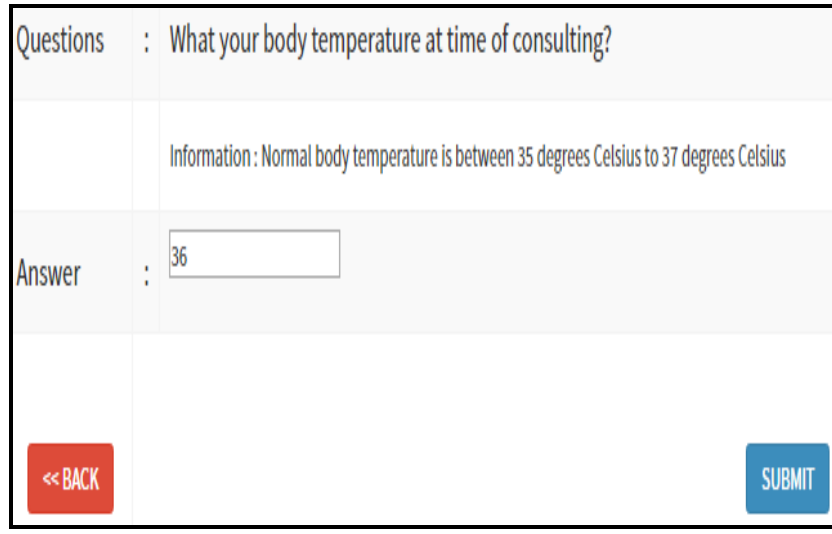

Fig. 4 Testing questions with fuzzy. 
Fig. 5 is a test of Expert System for Dental and Oral Diseases using Fuzzy Logic Method and Certainty Factor Method with a question containing the certainty level of users. The certainty level of users obtain input values 0 until 100 based on certainty level, such as: not sure, sure and very sure.

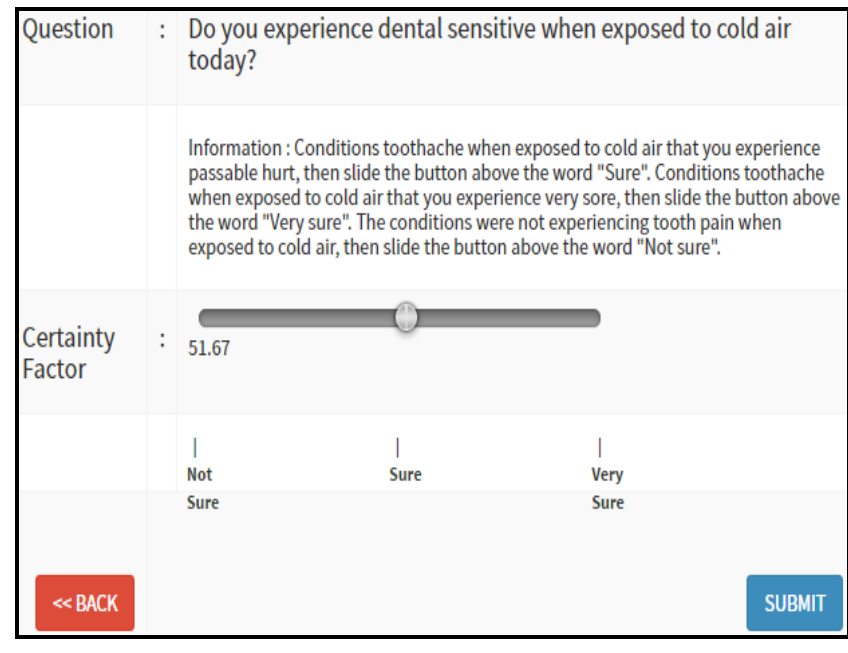

Fig. 5 Testing questions with certainty level.

Fig. 6 is a test of Expert System for Dental and Oral Diseases using Fuzzy Logic Method and Certainty Factor Method with crips symptom of users. Answer input of users, such as fig. 6 is answer "yes" or "no" and the values of "yes" is 100, while the values of "no" is 0 in consultation.

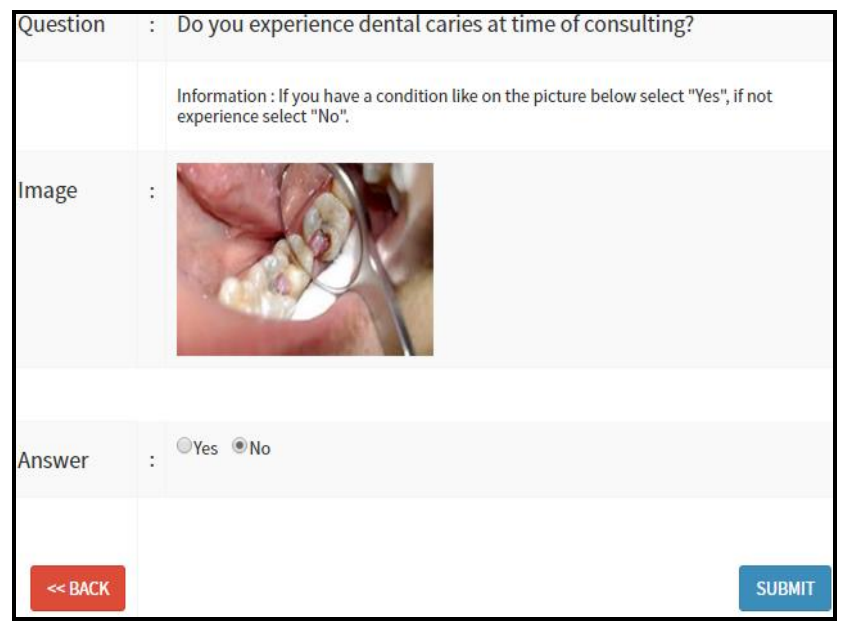

Fig. 6 Testing questions with image.
Application of Fuzzy Logic Method and Certainty Factor Method explained as follows.

a. Determine the degree of certainty of experts related to fraktur dental disease symptoms associated with using formulas 8, so they can get the Certainty Factor of experts, such as.

$$
\begin{aligned}
& C F(\text { sensitive teeth when exposed to cold air })= \\
& 0,4-0,2=0,2 \\
& C F(\text { tooth ache })=0,5-0,2=0,3 . \\
& C F(\text { sensitive teeth })=0,8-0,2=0,6 \text {. } \\
& C F(\text { gum pain when chewing or brushing teeth })= \\
& 0,6-0,2=0,4
\end{aligned}
$$

b. The value of the certainty degree the symptoms obtained by using the formula 1-6 in Figure 2 or Figure 3 on Expert System for Dental and Oral Disease as follows.

$$
\begin{aligned}
& \mu_{\text {Sensitive teath when expoved to toold air }}(50,71)=\left\{\frac{70-51,67}{70-50} ; 50 \leq 51,67 \leq 70\right\}=0,92 \text {. } \\
& \mu_{\text {Tooth ache }}(54,00)=\left\{\frac{70-54,00}{70-50} ; 50 \leq 54,00 \leq 70\right\}=0,80 \text {. } \\
& \mu_{\text {Sensitive teeth }}(100)=\{1 ; 100 \geq 70\}=1 \text {. } \\
& \mu_{\text {Gumpain when chewing or brushing teth }}(55,33)=\left\{\frac{70-55,33}{70-50} ; 50 \leq 54,00 \leq 70\right\}=0,73 \text {. }
\end{aligned}
$$

Table 3 show that performance as the result of comparation

Table 3: Fuzzification

\begin{tabular}{|l|l|l|l|}
\hline \multicolumn{1}{|c|}{ Questions } & Answer & CF_User & Fuzzy \\
\hline $\begin{array}{l}\text { Do you experience } \\
\text { dental pain when eat } \\
\text { or drink hot or cold } \\
\text { from one week ago? }\end{array}$ & 0 & 1 & $\begin{array}{l}\text { Not } \\
\text { sure }\end{array}$ \\
\hline $\begin{array}{l}\text { Do you experience } \\
\text { halitosis at time of } \\
\text { consulting? No }\end{array}$ & 1 & $\begin{array}{l}\text { Very } \\
\text { sure }\end{array}$ \\
\hline $\begin{array}{l}\text { Do you experience } \\
\text { sensitive teeth } \\
\text { suddenly without any } \\
\text { stimulation? No }\end{array}$ & 1 & $\begin{array}{l}\text { Not } \\
\text { sure }\end{array}$ \\
\hline $\begin{array}{l}\text { Do you experience } \\
\text { dental sensitive when } \\
\text { exposed to cold air } \\
\text { today? }\end{array}$ & 51,67 & 0,92 & Sure \\
\hline $\begin{array}{l}\text { Do your gums feel } \\
\text { pain while chewing } \\
\text { or brushing your } \\
\text { teeth? }\end{array}$ & 55,33 & 0,73 & Sure \\
\hline
\end{tabular}




\begin{tabular}{|c|c|c|c|}
\hline $\begin{array}{l}\text { Do you have swollen } \\
\text { gums and redness at } \\
\text { time of consulting? }\end{array}$ & 0 & 1 & $\begin{array}{l}\text { Not } \\
\text { sure }\end{array}$ \\
\hline $\begin{array}{l}\text { Do you feel the itch } \\
\text { in the gum from one } \\
\text { week ago? }\end{array}$ & No & 1 & $\begin{array}{l}\text { Not } \\
\text { sure }\end{array}$ \\
\hline $\begin{array}{l}\text { Do you experience } \\
\text { tartar at time of } \\
\text { consulting? }\end{array}$ & No & 1 & $\begin{array}{l}\text { Not } \\
\text { sure }\end{array}$ \\
\hline $\begin{array}{lr}\begin{array}{l}\text { Do you } \\
\text { toothache }\end{array} & \text { have a } \\
\text { insomnia? } & \\
\end{array}$ & 52,00 & 0,90 & Sure \\
\hline $\begin{array}{l}\text { Do you experience } \\
\text { dental seem longer at } \\
\text { time of consulting? }\end{array}$ & 0 & 1 & $\begin{array}{l}\text { Not } \\
\text { sure }\end{array}$ \\
\hline $\begin{array}{l}\text { Do you have your } \\
\text { teeth dark or black? }\end{array}$ & No & 1 & $\begin{array}{l}\text { Not } \\
\text { sure }\end{array}$ \\
\hline Do your teeth loose? & No & 1 & $\begin{array}{l}\text { Not } \\
\text { sure }\end{array}$ \\
\hline $\begin{array}{l}\text { Do you fell teeth ache } \\
\text { one week ago, but } \\
\text { now it is gone? }\end{array}$ & No & 1 & $\begin{array}{l}\text { Not } \\
\text { sure }\end{array}$ \\
\hline $\begin{array}{l}\text { Do your teeth ache at } \\
\text { time of consulting? }\end{array}$ & 54,00 & 0,80 & Sure \\
\hline $\begin{array}{l}\text { Do your teeth are } \\
\text { sensitive without any } \\
\text { stimulation at time of } \\
\text { consulting? }\end{array}$ & Yes & 1 & $\begin{array}{l}\text { Very } \\
\text { sure }\end{array}$ \\
\hline $\begin{array}{l}\text { Do you have abscess } \\
\text { at your gum? }\end{array}$ & No & 1 & $\begin{array}{l}\text { Not } \\
\text { sure }\end{array}$ \\
\hline $\begin{array}{l}\text { Do your mouth there } \\
\text { is a wound that is big } \\
\text { enough at time of } \\
\text { consulting? }\end{array}$ & No & 1 & $\begin{array}{l}\text { Not } \\
\text { sure }\end{array}$ \\
\hline $\begin{array}{l}\text { Do you have your } \\
\text { mouth abscess? }\end{array}$ & 0 & 1 & $\begin{array}{l}\text { Not } \\
\text { sure }\end{array}$ \\
\hline $\begin{array}{lll}\begin{array}{l}\text { Do have you no } \\
\text { appetite? }\end{array} & & \\
\end{array}$ & No & 1 & $\begin{array}{l}\text { Not } \\
\text { sure }\end{array}$ \\
\hline $\begin{array}{l}\text { Do your mouth sores } \\
\text { spread at time of } \\
\text { consulting? }\end{array}$ & No & 1 & $\begin{array}{l}\text { Not } \\
\text { sure }\end{array}$ \\
\hline $\begin{array}{l}\text { Does your mouth feel } \\
\text { dry at time of } \\
\text { consulting? }\end{array}$ & No & 1 & $\begin{array}{l}\text { Not } \\
\text { sure }\end{array}$ \\
\hline $\begin{array}{l}\text { Do your saliva } \\
\text { thicker than usual at } \\
\text { time of consulting? }\end{array}$ & No & 1 & $\begin{array}{l}\text { Not } \\
\text { sure }\end{array}$ \\
\hline $\begin{array}{l}\text { What your body } \\
\text { temperature at time of } \\
\text { consulting? }\end{array}$ & 36 & 0,6 & $\begin{array}{l}\text { Not } \\
\text { sure }\end{array}$ \\
\hline $\begin{array}{l}\text { Do you experience } \\
\text { dental caries at time }\end{array}$ & No & 1 & $\begin{array}{l}\text { Not } \\
\text { sure }\end{array}$ \\
\hline
\end{tabular}

\begin{tabular}{|l|l|l|l|}
\hline of consulting? & & & \\
\hline $\begin{array}{l}\text { Do your gums bleed } \\
\text { when brushing your } \\
\text { teeth today? }\end{array}$ & No & 1 & $\begin{array}{l}\text { Not } \\
\text { sure }\end{array}$ \\
\hline $\begin{array}{l}\text { Do you experience } \\
\text { stomatitis at time of } \\
\text { consulting? }\end{array}$ & 0 & 1 & $\begin{array}{l}\text { Not } \\
\text { sure }\end{array}$ \\
\hline $\begin{array}{l}\text { Does your mouth feel } \\
\text { pain at time of } \\
\text { consulting? }\end{array}$ & 0 & 1 & $\begin{array}{l}\text { Not } \\
\text { sure }\end{array}$ \\
\hline
\end{tabular}

c. Results of certainty factor of experts has the same value with $z i$ because $z i$ is the value of the weight of an experts decision. Value weight of an expert $(z i)$ and value weight of a user (wi) can be followed by defuzzification Formula 7. The results obtained, as follows.

Final Result $=\frac{(0,92 * 0,2)+(0,80 * 0,3)+(1 * 0,6)+(0,73 * 0,4)}{0,2+0,3+0,6+0,4}=\frac{1,316}{1,5}=0,8773$

d. Results of defuzzification between an expert and a user, namely 0,8773. The results obtained from the defuzzification continue to find value of certainty factor hypothesis (disease) of each symptom using the formula 9. So, the results of the calculation of Certainty Factor hypothesis (disease), i.e:

$C F_{\text {Sensitive teeth when exposed to cold air }}=0,8773$ *

$0,2=0,1755$

$$
\begin{aligned}
& C F_{\text {Tooth ache }}=0.8773 * 0.3=0.2632 \\
& \quad C F_{\text {Sensitive teeth }}=0.8773 * 0.6=0.5264 \\
& \quad C F_{\text {Gum pain when chewing or brushing teeth }}=0.8773 * 0.4=0.351
\end{aligned}
$$

e. The final results of the Expert System for Dental and Oral Diseases by using Formula 10. So, the results of the calculation some rules that lead to the same disease, i.e:

$$
\begin{aligned}
& C F_{\text {Sensitive teeth when exposed tocold air }}=(0,1755+0)-(0,1755 * 0)=0,1755 \\
& C F_{\text {Tooth ache }}=(0,2632+0,1755)-(0,2632 * 0,1755)=0,3925 \\
& C F_{\text {Sensitive teeth }}=(0,5264+0,3925)-(0,5264 * 0,3925)=0,7123 \\
& C F_{\text {Gum pain when chening or brushing teath }}=(0,351+0,7123)-(0,351 * 0,7123)=0,81
\end{aligned}
$$

The final result of the Expert System for Dental and Oral Diseases is 0,81 or 81 percent for the diagnosis result of fraktur dental diseases. Overall final result is in Fig. 6. 


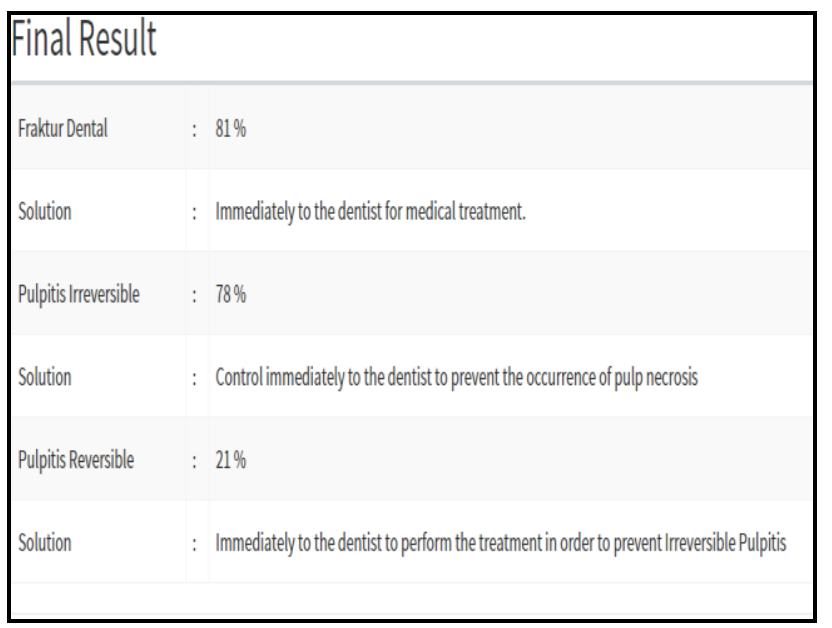

Fig. 6 Final result.

Fig. 7 is the system will not find of dental and oral diseases, if the user answered "not sure" or "no" with a normal body temperature on each question.

\section{Final Result}

\section{You do not experience any illness}

Fig. 7 No diseases found.

\subsection{Accuracy}

Function of accuracy is to make sure the diagnosis is based on the performance of the system carried out by experts with multiple users. Accuracy is done using the method of verification. Verification method is a similarity search method of diagnosis based on expert data with user data on the system. Accuracy results can indicate the degree of similarity Expert System Diagnosis of Dental and Oral Diseases developed with expert. Accuracy testing by an expert, namely a dentist, conducted by testing as many as 10 different cases.

The average diagnosis percentage of each case then calculation based on experts and user for each case tested. The formula to determine the average value in each case obtained by the results expert as follows.
Average Expert $=\frac{\sum_{i=1}^{N} \text { Result of Diagnosis Expert }}{N}$

Average Expert: The average yield of expert in each case.

$\sum_{i=1}^{N} R_{e s u l t}$ of Diagnosis Expert $t_{\mathrm{i}}$ The total amount of the percentage of disease in each case.

$N$ : The total number of diseases in each case.

The formula to determine the average value in each case the user as follows.

Average User $=\frac{\sum_{i=1}^{N} \text { Result of Diagnosis } U_{\text {ser }}}{N}$

Average User: The average yield of user in each case.

$\sum_{\mathrm{I}=1}^{N}$ Result of Diagnosis User $\quad$ : The total amount of the percentage of disease in each case.

$N$ : The total number of diseases in each case.

The formula to Determine the results of the comparison done by an expert and a user in each case as follows.

Defference $=\frac{\| \text { Average Expert }{ }_{\mathrm{i}}-\text { Average User }_{\mathrm{i}} \|}{\text { Average Expert }} * 100 \%$

Difference : The average yield of the difference between the results of the average expert in each case with the results of the average user in each case by absolute value.

Average Expert : The results of the average expert in each case.

Average User : The results of the average user in each case.

Table 4: Accuracy

\begin{tabular}{|r|r|r|r|}
\hline Case & Expert (\%) & User (\%) & Difference (\%) \\
\hline 1 & 90,5 & 91 & 0,55 \\
\hline 2 & 65 & 66 & 1,53 \\
\hline 3 & 78 & 69,8 & 10,51 \\
\hline
\end{tabular}




\begin{tabular}{|r|r|r|r|}
\hline 4 & 63,5 & 66 & 3,94 \\
\hline 5 & 62,67 & 67,67 & 7,98 \\
\hline 6 & 52,5 & 47,5 & 9,52 \\
\hline 7 & 54,8 & 56,6 & 3,28 \\
\hline 8 & 73,5 & 77 & 4,76 \\
\hline 9 & 73 & 81,5 & 11,64 \\
\hline 10 & 0 & 0 & 0 \\
\hline \multicolumn{2}{|r|}{ Average of Defference } & & 5,37 \\
\hline
\end{tabular}

Accuracy in Table 4 is a table that shows the accuracy of Expert System of Dental and Oral Disease with Fuzzy and Certainty Factor. Comparison of the results obtained from the difference between the user diagnosis with the expert diagnosis in each different case to obtain comparative results of Expert System of Dental and Oral Disease with Fuzzy and Certainty Factor in each case. The performance of the Expert System of Dental and Oral Disease with Fuzzy and Certainty Factor is the difference between the percentage of the average yield of the whole comparison of diagnosis dental and oral diseases, with the formula Accuracy $=100 \%-$ Difference (14). The results of the calculation formula is 14 , which is Accuracy $=100 \%-5,37 \%=94,627 \%$ so the accuracy of Expert System Diagnosis of Oral and Dental Diseases is 94,627 percent.

\section{Conclusions}

Expert System of Dental and Oral Disease with Fuzzy and Certainty Factor done by applying two methods: Method of Fuzzy Logic and Method of Certainty Factor. The inputs of user are crips and fuzzy value to handle fuzziness of symptoms. Fuzzy Logic method is used to get the value of the user's trust, while Certainty Factor method serves to obtain a diagnosis. So, the performance of Expert System for Dental and Oral Disease Diagnosis using Fuzzy Logic Method and Certainty Factor Method has an accuracy of $94,627 \%$. The accuracy of the results obtained from the comparison data entered experts with data from all users.

\section{Acknowledgments}

Our thank goes to Department of Information Technology Udayana University, Bali, who has helped organize this research's Indonesia

\section{References}

[1] N. Allahverdi, and T. A. Akcan, "Fuzzy Expert System Design for Diagnosis of Periodontal Dental Disease", IEEE. 2011.
[2] A. M. A. K. Parewe, and W. F. Mahmudy, "Dental Disease Identification Using Fuzzy Inference System". Journal of Environmental Engineering \& Sustainable Technology, Vol. 03, No. 01, 2016, pp. 33-41.

[3] A. Makarios, and M. I. Prasetiyowati, "Rancang Bangun Sistem Pakar untuk Diagnosis Penyakit Mulut dan Gigi dengan Metode Fuzzy Logic", ULTIMATICS, Vol. 4, No. 2, 2012.

[4] R. A. Herlambang, "Sistem Pakar Mendiagnosa Penyakit Infeksi Gigi dan Mulut pada Manusia Menggunakan Metode Certainty Factor", 2013.

[5] I. P. B. Krisnawan, I. K. G. D Putra, and I. P. A. Bayupati, "Sistem Pakar Diagnosa Penyakit Kulit dan Kelamin Dengan Metode Certainty Factor dan Fuzzy Logic", Merpati, Vol. 2, No. 3, 2014.

[6] A. S. Honggowibowo, "Sistem Pakar Diagnosa Penyakit Tanaman Padi Berbasis Web dengan Forward dan Backward Chaining", TELKOMNIKA, Vol. 7, No. 3, 2009, pp.187-194.

[7] E. Setyarini, D. Putra, and A. Purnawan, "The Analysis of Comparison of Expert System of Diagnosing Dog Disease by Certainty Factor Method and Dempster-Shafer Method", IJCSI International Journal of Computer Science Issues, Vol. 10, No. 2, 2013, pp. 576- 584.

[8] P. Manik, and D. Putra, "Fuzzy Knowledge-based System with Uncertainty for Tropical Infectious Disease Diagnosis", IJCSI International Journal of Computer Science Issues, Vol. 9, No. 3, 2011, pp. 157-163.

[9] D. Putra, and P. Manik, "Fuzzy Expert System for Infectious Diseases by Certainty Factor", TELKOMNIKA, Vol. 9, No. 11, 2011, pp. 1-8.

[10] S. Hartati, and S. Iswanti, Sistem Pakar dan Pengembangannya, Yogyakarta: Graha Ilmu, 2008.

[11] A. Bakar, Kedokteran Gigi Klinis Edisi 2, Yogyakarta: CV. Quantum Sinergis Media, 2015.

[12] B. Thalib, Perawatan Gigi Fraktur dengan Mahkota, Health and Education Indonesia, 2013.

[13] D. P. S. Dewi, Sistem Pakar Diagnosa Penyakit Jantung dan Paru dengan Fuzzy Logic dan Certainty Factor, Merpati. Vol. 2, No. 3, 2014.

[14] Wulandari, Pembuatan Sistem Pendukung Keputusan Berbasis Teori Fuzzy untuk Mengembangkan Suatu Produk Baru, Journal Sains Teknologi dan Industri, Vol 2., No. 2, 2005.

[15] S. Kusumadewi, Artificial Intelligence (Teknik dan Aplikasinya), Yogyakarta: Graha Ilmu, 2003.

[16] J. Giarratano, and G. Riley, Expert Systems Principles and Programming 4th Edition, Boston: PWS Publishing Company, 2005.

I Gede Billy Ambara Putra studied Information Technology in Departement of Information Technology, Faculty of Engineering, Udayana University since August 2013. This time, working his research for $\mathrm{S}$.Ti. degree in Information Technology.

Prof. Dr. I Ketut Gede Darma Putra, S.Kom. M.T. received his S.Kom degree in Informatics Engineering from Institut Teknologi Sepuluh Nopember University, his M.T. degree in Electrical Engineering from Gajah Mada University and his Dr. degree in Electrical Engineering from Gajah Mada University, his Prof. 
IJCSI International Journal of Computer Science Issues, Volume 14, Issue 3, May 2017

ISSN (Print): 1694-0814 | ISSN (Online): 1694-0784

www.IJCSI.org

degree from Udayana University. He is lecturer at Information Technology Department of Udayana University.

Ni Kadek Dwi Rusjayanthi, S.T., M.T received her S.T. degree in Udayana University, her M.T. degree in Informatics Engineering from Udayana University. She is lecturer at Information Technology Department of Udayana University. 